\title{
Gustavo Vega, Poéticas visuales, León, Instituto Leonés de Cultura, Diputación Provincial, 2008, s.p.
}

Genialidad artística, constancia, búsqueda de y en la poesía. Quizá puedan tales términos intentar una aproximación a la figura de Gustavo Vega. Y el presente libro-catálogo de su obra, editado con magnificencia por el Instituto Leonés de Cultura, recoge lo más fundamental. Además, lo hace desde la opción de la calidad. Quien nunca haya asistido a una exposición de la obra de Gustavo Vega tiene en él una oportunidad única de descubrir un mundo artístico y poético que no le dejará impasible.

Es necesario, sin embargo, hacer mención, primeramente, del prólogo, cuya autoría firma Belén Juárez -"Gustavo Vega: treinta años de imágenes y verbos proyectados sobre el infinito"-. En especial por el recorrido externo del poeta trazado en pocas páginas. Las colaboraciones, los premios, las exposiciones y demás actuaciones, como las de las nuevas tecnologías, quedan plasmadas en este útil prólogo. Pero querríamos destacar dos conceptos, que en él se consideran, y que nos parecen relevantes para el conocimiento de la obra de Gustavo Vega. Nos referimos, en primer lugar, a la afirmación de que “la poesía visual surge de una reflexión cognitiva". Que un poema, ya sea visual o no, nos emocione puede, en última instancia, depender de un estado de ánimo o de las preferencias estéticas. Cualquier poema visual de Gustavo Vega nos va a hacer pararnos delante de él e intentar pensarlo, aprehender la poesía que en él se transmite. Eso es también, en definitiva, un proceso cognitivo.

Hay una carga ancestral de pensamiento, liberado en la imagen que se combina con la letra, que nos capta y nos extasía. Fijémonos en uno de mis preferidos, "Soneto enmudecido y aplanado" (1985). El único texto se reduce al título y a una leyenda "Así es la vida". Es suficiente. Versos y rimas clásicas, asimilados a unas rayas sobre fondo de papel, a imitación de la armazón de un soneto. La genialidad radica en la fusión inesperada de trazos y letra imaginada. El espectador tiene que mirar hacia dentro, hacia sí mismo, si desea imaginar un texto posible. Todo acaba remitiendo a una reflexión interna sobre el proceso creativo. Es decir a un proceso filosófico-poético, cognitivo. Como señala la prologuista, "si tuviéramos que indagar en los orígenes de la Poesía Visual (sic), ello sin duda nos conduciría no sólo al Disco de Festos (Creta, 2500 a. C.), a Simias de Rodas, a Teócrito y otros creadores de tecnopaegnia del periodo helenístico griego, sino también al espíritu indagador de los presocráticos y demás protagonistas de la Filosofía Antigua, e incluso al origen mismo del pensamiento y a la necesidad de una reflexión capaz de coordinar la captación del mundo externo e interno con el entendimiento racional y la proyección emocional." 
El caligrama, tanto en la antigüedad como en la modernidad, ha compartido cauce expresivo con la lírica y con la pintura. Los emblemas de Alciato o los conceptos barrocos encerraban consignas filosóficas o morales. No es, en definitiva, un arte nuevo, el de la poesía visual, si nos situamos en una perspectiva amplia y sin límites temporales o estéticos. Sin embargo, pensamos que el acierto, la originalidad de Gustavo Vega radica en su heterodoxia vital y, sobre todo, artística. Como filósofo, invita a pensar en cada una de sus obras; es la parte cognitiva ya mencionada. Como poeta y artista, busca el eclecticismo de la imagen. Va más allá de los procesos cognitivos y inserta en la mente del lector-espectador la imaginería de la surrealidad. Lo racional y lo onírico suelen ir de la mano en la mayoría de trabajos del poeta berciano.

El resultado final pasa, en ocasiones, por el reino de lo metapoético, de la indagación sobre la expresión poética. Previo a la sección B, "De Poética", unas palabras evidencian esta voluntad de adentrarse en los estadios previos a la creación: “...con imágenes literarias, textos, o con imágenes visuales, son reflexiones sobre el propio quehacer poético...". Para introducirse plenamente en la poética de Gustavo Vega, conviene releer los poemas visuales agrupados en la sección B, "De Poética", que recoge la intencionalidad del poeta en el transcurso de años de reflexión artístico-poética. “Aclaración” (1980) puede leerse a modo de manifiesto de poética, de esfuerzo teórico-poético por aclarar los derroteros internos de su obra. Afirmaciones como "no es la palabra lo que ansío" o "deseo entre mis labios dedos" centran la obra veguiana en el cruce casi metafísico de la escritura -o palabra- con la plasticidad.

Existe, en general, herencia vanguardista en la disposición espacial de los textos, en el juego de palabras y conceptos, pero entre los límites de la cognitio y los abismos de lo surreal. Así, en “Caíste de la nada..." (1983), leemos, sobre un suelo embaldosado: "Caíste / de lanada a tu hueco, y / pronto descubriste el olvido, / if the moon smiled, o abandono / que muerde el engranaje de cualquier reloj / perdido, y cuánta soledad está / en muerte viva / dentro de una lata de sardinas." La poesía, es decir la poesía visual, de Gustavo Vega emerge, por tanto, de un rechazo hacia la limitación de la expresión meramente escrita, aunque apegada a la palabra; pero desde una perspectiva liberadora de ésta, imbricada en la reflexión ontológica del ser y en su plasmación artística.

Prevalece en la obra veguiana una decidida voluntad de mensaje, a pesar de todo. Como un romántico iniciático, el poeta sabe de la nada y, como Heidegger o Sartre, asume la noción del ser y de la nada para crear desde ésta, quizá a pesar de ésta. Dice en "Cada poema es..." (1980): "Cada poema es una INICIACIÓN, una BÚSQUEDA, un EXPERIMENTO ("All poetry is experimental poetry"), ... o una CONCLUSIÓN." Esta tensión creativa se resuelve, 
parcialmente, mediante un hallazgo, el de los Haikus Visuales, la sección M del libro-catálogo. Imagen, verbo, filosofía y trascendencia se mezclan en tales obras.

La brevedad y la sencillez de la milenaria tradición del haikú, ofrece al autor una nueva vía, ya intuida, que ahora -años 2004-07- le permite aunar intereses expresivos latentes. El instante plasmado a través de la frase reducida al mínimo, junto a la imagen, el cuadro o el objeto. La armonía entre ambos, verbo y forma plástica, genera una sugestión atemporal, preexistente, que define lo máximo a través de lo mínimo. En palabras del poeta, “...Es una llave que nos permite acceder a la iluminación poética que en su breve soporte se contiene. Es una anotación rápida, recreación, de un momento privilegiado, de una atmósfera espiritual." Los haikús de Gustavo Vega entroncan con las obras incluidas en la sección I, Mínimomaximalismo y derivados, desde la perspectiva visual, plástica.

Sin embargo, pensamos que es en la sección D, Discursivos: Caligramáticos y Acrósticos, donde se da también una búsqueda de la expresividad, mediante recursos verbales sobre los visuales. De ese modo, la imagen visual se ciñe más al texto, es decir, la letra subyuga temporalmente a la imagen plástica. Y aunque en los haikús Gustavo Vega haya alcanzado un sincretismo magistral, de todas formas, la citada sección de obras Discursivas -D-, permite al lector-espectador iniciarse en la poética veguiana desde una lectura primordial.

Se obliga al espectador a leer, por encima de mirar. La ontología del ser, bajo una perspectiva existencialista, de raigambre romántica no obstante, se resuelve en una superposición estética de verso e imagen. Para quien echase en falta la poesía discursiva, en esta sección puede hallar un tipo de poesía más filosófica que lúdica, sin dejar de serlo, siendo éste uno de los logros genuinos del autor. Bajo este equilibrio aparece un díptico, "No hay retorno" (1996), que se halla, a nuestro parecer, entre lo mejor de la poesía veguiana. En éste se leen versos como los siguientes, los cuales se transcriben sin poder respetar el espaciado y demás recursos propios de esta poesía, pero que creemos encierran algo de la esencia profunda del autor: "Ávidos de más vida, para encarnar el deseo, / a veces tatuamos la propia herrumbre/ con ríos de frescura / y falsas primaveras, con hipnotizadas aguas de alegría. / Pero, otras veces, inevitablemente se nos descorren / las tinieblas que aguantábamos con las manos / y nos saltan a la cara / para roernos los ojos con asco / las ratas ansiosas / de la muerte."

En definitiva, con Poéticas Visuales, Gustavo Vega se sitúa en uno de los poetas visuales indispensables. Durante lustros, ha ahondado en los veneros más lúcidos de sus capacidades expresivas, hasta alcanzar los niveles estéticos que ahora podemos vislumbrar aquí. Sin duda, cada vez que un lector-espectador se enfrenta a una obra veguiana siente una suspensión temporal, la que conlleva la antítesis de una fractura-fusión de los criterios aprehendidos, 
perseguida por el autor. Es la experiencia estética lograda y ofrecida al unísono por Gustavo Vega en cada una de sus obras, de sus objetos o de sus actos artístico-literarios.

Juan Carlos Merchán Ruiz 